\title{
RECHTSTAAT DAN KONSTITUSIONALISME DALAM PEMIKIRAN ABDURRAHMAN WAHID DAN HASYIM MUZADI
}

\author{
Mustofa \\ Fakultas Syariah dan Hukum, Universitas Islam Negeri (UIN) Sunan Gunung Djati Bandung \\ J. A.H. Nasution No. 105 Cibiru Bandung, 40614 \\ E-mail: mustofahasan@uinsgd.ac.id
}

\begin{abstract}
Rechtstaat and Constitutionalism in the Thought of Abdurrahman Wahid (1940-2009) and Hasyim Muzadi (1944-2017). This study aims to explore the thoughts of Abdurrahman Wahid and Hasyim Muzadi about rechtstaat and constitutionalism. This study uses the juridical-normative method with the historical-normative approach and the type of qualitative data. The data sources consist of primary, secondary, and tertiary data obtained from the number of literature and documentation. While the data collection techniques are obtained from book reviews and documentation. Data analysis method is conducted deductively and inductively. The result of this study reveals that the state law and the constitutionalism in the thoughts of Abdurrahman Wahid and Hasyim Muzadi refer to the constitution of Madinah and civil society in relation to religion and state. Abdurrahman Wahid and Hasyim Muzadi can be positioned as substantial, pluralist, nationalist, and humanist religious thinkers. Abdurrahman Wahid and Hasyim Muzadi's contribution has proved to give improvements in strengthening the relationship between religion and state in Indonesia and has implications for rechtstaat's future and constitutionalism in the Islamic legal system in Indonesia. The critical findings of this research are the thoughts of Abdurrahman Wahid, and Hasyim Muzadi provides enlightenment of idea and solution to the problematic rechtstaat with a cultural-religious approach.
\end{abstract}

Keywords: rechtstaat; constitutionalism; Abdurrahman Wahid; Hasyim Muzadi; thought.

\begin{abstract}
Abstrak: Rechtstaat dan Konstitusionalisme dalam Pemikiran Abdurrahman Wahid (1940-2009) dan Hasyim Muzadi (1944-2017). Penelitian ini bertujuan untuk mengungkapkan pemikiran Abdurrahman Wahid dan Hasyim Muzadi tentang rechtstaat dan konstitualisme. Penelitian ini menggunakan metode yuridis-normatif dengan pendekatan historis-normatif serta jenis data kualitatif. Sumber data terdiri atas data primer, sekunder, dan tertier yang diperoleh dari sejumlah literatur dan dokumentasi. Sedangkan teknik pengumpulan data diperoleh dari book review dan dokumentasi. Metode analisis data dilakukan secara deduktif dan induktif. Hasil penelitian ini mengungkapkan bahwa negara hukum dan konstitualisme dalam pemikiran Abdurrahman Wahid dan Hasyim Muzadi merujuk kepada konstitusi Madinah dan civil society dalam hubungannya dengan agama dan negara. Abdurrahman Wahid dan Hasyim Muzadi dapat diposisikan sebagai pemikir muslim subtansialis, pluralis, nasionalis, dan tokoh agama humanis. Kontribusi pemikiran Abdurrahman Wahid dan Hasyim Muzadi terbukti memberikan kemajuan dalam memperkokoh hubungan agama dan negara di Indonesia dan berimplikasi terhadap masa depan rechtstaat dan konstitusionalisme dalam sistem hukum Islam di Indonesia. Temuan penting penelitian ini adalah pemikiran Abdurrahman Wahid dan Hasyim Muzadi yang memberikan pencerahan pemikiran dan solusi terhadap problematika rechtstaat dengan pendekatan kultural-religius.
\end{abstract}

Kata kunci: rechtstaat; konstitutionalisme; Abdurrahman Wahid; Hasyim Muzadi; pemikiran.

\section{Pendahuluan}

Abdurraham Wahid (selanjutnya disapa Gus Dur) cenderung menolak terhadap segala bentuk formalisasi agama. Segala hal yang berwajah syariatisasi atau Arabisasi sebagaimana diungkapkan Hamidah' selalu ditolak oleh Gus Dur.

Hamidah, "Pemikiran Neo-Modernisme Nurcholish Madjid-K.H. Abdurrahman Wahid: Memahami Perkembangan la juga menolak tentang keberadaan negara Islam. Sebab, pada dasarnya, Islam belum mempunyai konsep yang jelas dan terperinci tentang sistem negara. Menurutnya, nabi Muhammad Saw menata Madinah itu tidak kemudian membentuk

Pemikiran Intelektual Islam", Miqot: Jurnal Ilmu-ilmu Keislaman, Volume 35, Nomor 12011 , http://jurnalmiqotojs.uinsu.ac.id/index. php/jurnalmiqot/article/view/132/122, diakses 17 April 2018. 
negara Islam, tetapi membentuk negara Islami yang menurut Nurcholis Madjid disebut negara madani. Karena itu, yang dibutuhkan sebenarnya bukan memberikan label Islam, tapi nilai-nilai Islam lah yang harusnya menjadi landasan dan spirit dalam menjalankan pemerintahan atau negara. Jadi, Gus Dur lebih mencita-citakan masyarakat yang menjadikan Islam sebagai nilai dalam kehidupan sosial masyarakat, meski tidak harus hidup dalam bentuk negara Islam.

Berbicara masalah keislaman dan keindonesiaan, muara pemikiran Gus Dur yang kemudian menyemai ke dalam pemikiran keislaman dan kenegaraan itu, berasal dari pemikirannya mengenai pribumisasi Islam di Indonesia. Pemikiran Gus Dur ini pada awalnya menuai pro dan kontra. Fitriah ${ }^{2}$ mengatakan bahwa pro-kontra mengenai konsepsi pribumisasi Islam ini tidak bisa dihindarkan. Pada 8-9 Maret 1989, lebih kurang 200 kiai berkumpul di Pondok Pesantren Darut Tauhid Arjawinangun Cirebon untuk "mengadili" Gus Dur. Dari sini muncul beberapa kubu yang pro dan kontra atas gagasan Gus Dur terkait dengan pribumisasinya. Akan tetapi, sebagaimana diakui Gus Dur, ia bukanlah yang pertama yang memulai. la adalah generasi pelanjut dari langkah strategis yang pernah dijalankan oleh Wali Songo. Dengan langkah pribumisasi, menurutnya, Wali Songo berhasil mengislamkan tanah Jawa tanpa harus berhadapan dan mengalami ketegangan dengan budaya setempat.

Pribumisasi Islam pada prinsipnya mengupayakan agar ajaran-ajaran Islam benar-benar membumi dalam setiap ruang dan waktu yang dilaluinya. Secara sederhana, wacana pribumisasi Islam ini dapat dipahami sebagai upaya untuk melindungi proses asimilasi dan akulturalisasi nilainilai Islam dengan kebudayaan lokal Indonesia yang berlangsung secara alamiah. Tujuan akhirnya adalah agar tradisi-tradisi yang terbentuk dari proses asimilasi dan akulturasi ini tetap dapat diakui sebagai budaya Islami.

Di antara pemikiran Abdurrahman Wahid tentang keislaman dan keindonesiaan adalah

${ }^{2}$ Fitriah, Ainul, "Pemikiran Abdurrahman Wahid tentang Pribumisasi Islam", Teosofi: Jurnal Tasawuf dan Pemikiran Islam, Volume 3, Nomor 1 Juni 2013, http://teosofi.uinsby.ac.id/index. php/teosofi/article/view/43/40, diakses 17 April 2018. pemikirannya mengenai Islam, rechtsstaat, dan konstitusionalisme. Wujud lain sebenarnya juga dapat dilihat seperti penelitian M. Khoirul Hadi yang mengungkapkan "pribumisasi pendidikan Islam ala Gus Dur"3 dan konsep multikultural yang diteliti oleh Wasino ${ }^{4}$. Konsep rechtsstaat dan Konstitusionalisme dalam Pemikiran Abdurrahman Wahid (lahir 1940 dan wafat 2009) ini kemudian disandingkan dengan pemikiran K.H. Hasyim Muzadi (lahir 1944 dan wafat 2017). Pemikiran kedua tokoh ini menarik untuk dianalisis, bukan saja karena keduanya adalah mantan Ketua Umum Pengurus Besar Nahdatul Ulama (PBNU), tetapi karena pemikirannya memiliki kesamaan dalam membangun bangsa dan negara.

Fenomena rechtsstaat atau negara hukum dan konstitusionalisme dalam pemikiran Gus Dur dan Hasyim Muzadi sangat urgen untuk dibahas. Selama beberapa dekade, diskursus hubungan agama dan negara dalam pemikiran hukum Islam ditentukan dalam tiga poin ${ }^{5}$ sebagai berikut. Pertama, Islam dipandang sebagai agama yang sempurna dan serba lengkap mengatur segala aspek kehidupan manusia termasuk di dalamnya masalah politik dan ketatanegaraan. Kedua, Islam dipahami dalam pengertian negaranegara Barat yakni antara agama dan negara tidak ada hubungannya, masing-masing terpisah satu sama lain. Ketiga, Islam dipahami secara substantif, meskipun tidak diatur secara tegas masalah politik dan ketatanegaraan serta tidak pula memisahkan antara keduanya, akan tetapi di dalamnya terdapat seperangkat prinsip-prinsip dan asas-asas tentang politik dan ketatanegaraan.

Pola hubungan agama dan negara dalam pemikiran hukum Islam, secara internal bukan hanya tampak pada implementasi prinsipprinsip dan asas-asas politik Islam dalam sistem pemerintahan dan negara, tetapi juga secara eksternal dipengaruhi oleh latar belakang sejarah, sosial, budaya, dan ekonomi, serta peradaban

\footnotetext{
${ }^{3}$ Hadi, M. Khoirul, "Abdurrahman Wahid dan Pribumisasi Pendidikan Islam”, Hunafa: Jurnal Studia Islamika, Vol.12, No. 1, Juni 2015: 183-207.

${ }^{4}$ Wasino, "Indonesia: From Pluralism to Multiculturalism", Paramita: Historical Studies Journal, Vol 23, No. 2, 2013, https://journal.unnes.ac.id/nju/index.php/paramita/article/ view/2665/2733, diakses 20 April 2018.

${ }^{5}$ Munawir Sjadzali, Islam dan Tata Negara, (Jakarta: UI Press, 1991), h. 1-3.
} 
pemikiran yang berbaur dalam tradisi politik dan hukum dalam masyarakat muslim itu sendiri. Hal ini telah mendukung pandangan pemikiran bahwa pada masa awal kemunculannya, Islam seringkali dihubungkan dengan pengalaman kejayaan di bidang politik. ${ }^{6}$

Pengkajian atas gagasan Gus Dur dan Hasyim Muzadi tentang Rechtsstaat dan Konstitusionalisme dilatarbelakangi beberapa alasan. Pertama, diskursus paling menarik dalam pandangan Gus Dur dan Hasyim Muzadi untuk membangun civil society yang berdaya. Hal itu didasarkan kepada keputusan NU untuk kembali ke Khittah 1926. Bagi sebagian pengamat, kembalinya NU ke Khittah 1926 dinilai sebagai sebuah jawaban yang tepat dan strategis di masa mendatang. Dengan kembali ke khittah, secara kelembagaan, NU memutuskan untuk tidak terlibat lagi dalam politik praktis. Ini artinya bukan berarti NU tidak berpolitik. NU pada dasarnya tetap berpolitik, hanya orientasi politiknya mengalami perubahan.

Terdapat duabelas prinsip yang merupakan pilar utama dalam menyangga berdiri tegaknya suatu negara modern, sehingga dapat disebut rechtsstaat dalam arti yang sebenarnya. Adapun keduabelas prinsip tersebut adalah: (1) supermasi hukum (supermacy of law); (2) persamaan dalam hukum (equality before the law); (3) asas legalitas (due process of law); (4) pembatasan kekuasaan; (5) organ-organ eksekutif independen; (6) peradilan yang bebas dan tidak memihak; (7) peradilan tata usaha negara; (8) peradilan tata negara (constitusional court); (9) peradilan hak asasi manusia; (10) bersifat demokratis (democratische rechtsstaat); (11) berfungsi sebagai sarana mewujudkan tujuan negara (welfare rechtsstaat); dan (12) transparansi dan kontrol sosial.7

Pada Musyawaranh Nasional Alim Ulama NU di Situbondo (1983), Pancasila diterima sebagai dasar negara. Sedangkan Islam tetap dijaga sebagai akidah. Antara akidah beragama dan dasar bernegara tidak dibenturkan. Pancasila yang memuat sila Ketuhanan Yang Maha Esa

\footnotetext{
${ }^{6}$ Ahmad Syafì Ma'arif, Islam dan Masalah Ketatanegaraan, (Jakarta: Bulan Bintang, 1993), h. i.

7 Jimly Asshiddiqie,Gagasan Kedaulatan Rakyat dalam Konstitusi dan Pelaksanaannya di Indonesia, (Jakarta: Ichtiar Baru-van Hoeve, 1994), h. 14-15.
}

merupakan bentuk pengamalan syariat Islam. ${ }^{8}$

Berkenaan dengan uraian di atas, yang menjadi fokus tulisan ini adalah (1) pemikiran Gus Dur dalam pembaharuan Islam di Indonesia, (2) gagasan Gus Dur dan Hasyim Muzadi tentang Negara berdasarkan hukum, Rechtsstaat dan Konstitusionalisme dalam konteks hubungan antara agama dengan negara di Indonesia, dan (3) kontribusi dan implikasi gagasan Gus Dur dan Hasyim Muzadi tersebut bagi masa depan perkembangan agama dan negara dalam hukum Islam di Indonesia.

\section{Metode}

Penelitian ini menggunakan metode yuridisnormatif dengan pendekatan historis-normatif serta jenis data kualitatif. Sumber data terdiri atas data primer, sekunder, dan tertier yang diperoleh dari sejumlah literatur dan dokumentasi. Sedangkan teknik pengumpulan data diperoleh dari book review dan dokumentasi. Metode analisis data dilakukan secara deduktif dan induktif. Sementara itu, kerangka teori dilakukan melalui (1) grand theory, yakni teori kredo dan teori kedaulatan Tuhan; (2) middle range theory, yakni teori perubahan sosial dan perubahan hukum; dan (3) applied theory, yaitu teori Konstitusi Madinah dan teori negara hukum.

Teori kredo yaitu teori yang mengharuskan pelaksanaan hukum Islam oleh mereka yang telah mengucapkan dua kalimah syahadat sebagai konsekuensi logis dari pengucapan kredonya9. Teori ini sesungguhnya kelanjutan dari prinsip tauhid dalam filsafat hukum Islam. Prinsip tauhid yang menghendaki setiap orang yang menyatakan dirinya beriman kepada kemahaesaan Allah swt, maka ia harus tunduk kepada apa yang diperintahkan-Nya, yakni taat kepada-Nya dan sekaligus taat kepada Rasulullah saw dengan mengikuti sunahnya.

Teori Kredo ini sama dengan teori hukum

8 Keputusan itulah yang dikukuhkan oleh Muktamar NU XXVII yang berlangsung tanggal 8-12 Desember 1984 di Situbondo. Di tempat yang sama dengan berlangsungnya Musyawarah Nasional, Muktamar yang bersejarah dihadiri oleh Presiden dan para Menteri. Lihat: Einar Martahan Sitompul, NU dan Pancasila (Jakarta: Sinar Harapan, 1989), h. 167.

9 Juhaya S Praja, Filsafat Hukum Islam, (Tasikmalaya: Lathifah Press dan Fakultas Syariah IAILM, 2009), h. 133. 
yang dijelaskan oleh H.A.R. Gibb ${ }^{10}$. Menurutnya, orang Islam yang telah menerima Islam sebagai agamanya berarti ia telah menerima otoritas hukum Islam atas dirinya. Teori Gibb ini sama dengan apa yang telah diungkapkan oleh imam mazhab seperti Imam Syafiì dan Imam Abu Hanifah ketika mereka menjelaskan teori mereka tentang politik hukum internasional Islam dan hukum pidana Islam. Mereka mengenal teori teritorialitas dan nonteritorialitas. Teori teritorialitas dari Imam Abu Hanifah menyatakan bahwa seorang muslim terikat untuk melaksanakan hukum Islam sepanjang ia berada di wilayah hukum tempat hukum Islam diberlakukan. Sementara teori nonteritorialitas dari Imam Syafii menyatakan bahwa seorang muslim selamanya terikat untuk melaksanakan hukum Islam di mana pun ia berada, baik di wilayah hukum ketika hukum Islam diberlakukan, maupun di wilayah hukum yang tidak memberlakukan hukum Islam.

Teori sosial dan perubahan hukum sebagai midle theory dalam penelitian ini adalah penyerapan hukum Islam oleh masyarakat adat dan ini merupakan sebuah fenomena yang terjadi di Indonesia. Teori ini digunakan untuk menjelaskan lebih lanjut masalah penyerapan hukum Islam oleh masyarakat di Indonesia. Dalam hal ini, muncullah dua teori, yakni teori receptio in complexu yang dikemukaan oleh Lodewijk Willem Cristian Van Den Berg (1845-1927) dan theory receptie Christian Snouck Hurgronye (1857-1936). Dalam teori receptie in complexu disebutkan bahwa bagi orang Islam yang berlaku penuh adalah hukum Islam sebab dia telah memeluk Islam walaupun dalam pelaksanaannya masih terdapat penyimpanganpenyimpangan. Sementara dalam teori receptie disimpulkan bahwa hukum Islam di Indonesia baru dapat diterima dan berlaku ketika telah diterima oleh hukum adat. Teori kedua ini sebenarnya bertujuan politis, yakni agar semangat umat Islam Aceh ketika itu melemah untuk menjalankan syariat Islam yang akan membahayakan kepentingan pemerintah Hindia Belanda.

Kedua teori di atas kemudian dibantah oleh

${ }^{10}$ H.A.R. Gibb, The Modern Trends in Islam, (Chicago: The University of Chicago Press, 1950) dan bisa juga dilihat Sajuti Thalib, Receptio A Contratrio, Hubungan Hukum Adat dan Hukum Islam, (Jakarta: Bina Aksara, 1985), Cet. ke-5, h. 5
Hazairin dikenal dengan teori receptie exit. Beliau berpendapat bahwa banyak aturan pemerintah Hindia Belanda yang bertentangan dengan UUD 1945. Pertentangan tersebut terdapat pada pembukaan Undang-Undang Dasar Alinea ke III dan Alinea ke IV serta pada Pasal 29 UndangUndang Dasar 1945. Kesimpulan dari teori ini adalah:

1. Teori receptie telah patah; tidak berlaku dan exit dari tata negara Indonesia sejak Tahun 1945 dengan merdekanya bangsa Indonesia dan memulai berlakunya UUD 1945 dan dasar negara Indonesia. Demikian pula keadaan itu setelah adanya Dekrit Presiden tanggal 5 Juli 1959 untuk kembali pada UUD 1945.

2. Sesuai dengan UUD 1945 pasal 29 ayat 1 maka negara Republik Indonesia berkewajiban membentuk hukum nasional Indonesia bahannya adalah hukum agama. Negara mempunyai kewajiban kenegaraan untuk itu.

3. Hukum agama yang masuk dan menjadi hukum Nasional Indonesia itu bukan hukum Islam saja, melainkan juga hukum agama lain untuk pemeluk agama lain. Hukum agama di bidang hukum perdata dan hukum pidana diserap menjadi hukum nasional Indonesia. Istilah hukum baru Indonesia dengan dasar Pancasila"1.

Applied theory yang digunakan adalah teori perubahan hukum dan seperangkat kaidah hukum Islam mengenai perubahan hukum. Teori perubahan hukum digunakan untuk mengetahui unsur-unsur internal dan eksternal masyarakat yang menjadi pengubah hukum. Perubahan hukum tidak bisa lepas dari perubahan sosial, karena hukum sebagai subsistem dari sistem sosial' ${ }^{12}$. Applied theory ini juga menggunakan seperangkat kaidah-kaidah hukum Islam yang berkenaan dengan perubahan hukum. Kaidahkaidah fighiyah yang berhubungan dengan

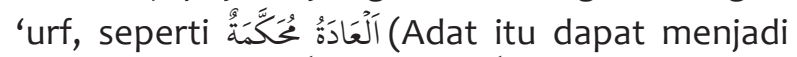

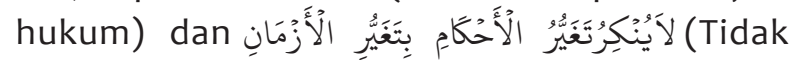
dapat dipungkiri bahwa perubahan hukum itu berhubungan dengan perubahan masa). Kaidah-

"Juhaya S. Praja, Teori Hukum dan Aplikasinya, (Bandung: Pustaka Setia, 2011), h. 81.

${ }^{12}$ Abdul Manan, Aspek-aspek Pengubah Hukum, (Jakarta: Kencana Prenada Media, 2005), h. 24. 
kaidah tersebut memberikan pedoman bahwa hukum Islam memiliki sifat elastis sehingga akan bisa selaras dengan perkembangan zaman.

\section{Gagasan Tentang Rechtsstaat Abdurrahman Wahid}

Gus Dur sangat konsisten dengan pemikirannya bahwa negara tidak harus berbentuk negara Islam secara formal, demikian pula dalam pelaksanaan hal-hal kenegaraan.Dalam hal ini, Santalia mengatakan bahwa negara dalam perspektif Gus Dur adalah al-hukum, yakni hukum atau aturan ${ }^{13}$. Dengan kata lain, Islam tidak mengenal konsep pemerintahan yang defenitif, tetapi yang terpenting dalam Islam adalah etika kemasyarakatan dan komunitas. ${ }^{14}$ Bahkan dalam persoalan yang paling pokok, yakni suksesi kekuasaan, menurut Gus Dur, ternyata Islam tidak konsisten. Terkadang memakai istiskhlaf, bay'at, atau ahl al-hall wa al-'aqd. Padahal suksesi merupakan masalah yang cukup penting dalam urusan kenegaraan. la memberikan catatan jika memang Islam mempunyai konsep, tentu tidak terjadi demikian. Bagi Gus Dur, Islam memang sengaja tidak mengatur konsep kenegaraan agar ia dapat diterima oleh semua entitas budaya. Menurut Gus Dur, yang ada hanyalah komunitas agama (kuntum khayr ummah ukhrijat li al-nâs). Jadi, khayr ummah bukan khayr dawlah atau khayr jumhûriyah, apalagi khayr mamlakah. ${ }^{15}$

Patut digaris bawahi bahwa gagasan Gus Dur yang menyatakan bahwa umat Islam sebenarnya tidak perlu lagi merasa kesulitan untuk mencari kaitan antara Islam dan wawasan kebangsaan. Akan tetapi, ia mengakui bahwa pengertian bangsa dalam rumusan Alquran yaitu kuntum khayr ummah ukhrijat li an-nâs, terbatas hanya pada bangsa sebagai satuan etnis yang mendiami teritorial bersama. Sedangkan wawasan kebangsaan di masa modern ini pengertiannya

${ }^{13}$ Santalia, Indo, "K.H. Abdurrahman Wahid: Agama dan Negara, Pluralisme, Demokratisasi, dan Pribumisasi”, Jurnal AlAdyan,Vol.1, No. 2, Desember 2015.

${ }^{14}$ Abdurrahman Wahid dalam kata pengantarnya untuk Buku, Greg Fealy dan Greg Barton (ed.), Tradisionalisme Radikal: Persinggungan Nahdlatul Ulama-Negara, (Yogyakarta: LKiS, 1997).

${ }^{15}$ Abdurrahman Wahid, “Merumuskan Hubungan Ideologi Nasional dan Agama", dalam Kacung Marijan dan Ma'mun Murod al-Brebesy, Abdurrahman Wahid Mengurai Agama dan Negara (Jakarta: Grasindo, 1999), h. 87. sudah lain, yakni satuan politik yang didukung oleh ideologi nasional. Penjelmaan pengertian ini menurut Gus Dur ialah konsep negara-bangsa (nation state). Di abad modern ini, mau tidak mau Islam harus mau berinteraksi dengan sederetan fenomena yang secara global merupakan nation state. ${ }^{16}$

Perdebatan hukum Islam di tengah pluralitas hukum nasional tampaknya merupakan kewajaran, sebagai konsekuensi dari induk hukum nasional (Kitab Undang-Undang Hukum Perdata) sebagai warisan Belanda dan Perancis dari sistem hukum kontinental, civil law system, dengan ajaran individualism, liberalism and individual rights yang tidak sesuai dengan kesadaran hukum Indonesia. ${ }^{17}$ Pergumulan tersebut telah diupayakan solusinya sejak lahirnya Undang-Undang Nomor 1 Tahun 1946 melalui asas konkordansi, yang sesungguhnya sangat terkait dengan dinamika perkembangan politik hukum nasional. ${ }^{18}$ Dalam pergumulan politik nasional, beberapa hukum nasional telah lahir sejak kemerdekaan, Orde Lama, Orde Baru bahkan hingga era Reformasi dan masih menjadi polemik. Hal ini, tampak misalnya dalam perjalanan Undang-Undang Nomor 1 Tahun 1974 tetang Perkawinan, Kompilasi Hukum Islam (Instruksi Presiden Nomor 1 Tahun 1991), Undang-Undang Nomor 41 Tahun 2004 tentang Wakaf, Peraturan Daerah berbasis Syariah, dan lain-lainnya. ${ }^{19}$ Sementara itu, Hasyim Muzadi menyatakan bahwa hukum Islam dilarang menjadi Peraturan Daerah (Perda) bernuansa syariah. Menurutnya, syariat Islam seharusnya ada dalam konteks civil society bukan nation state karena hal tersebut dikhawatirkan memicu perpecahan bangsa dan negara.

Fenomena yang demikian dapat dibenarkan, antara lain karena politik hukum yang berpengaruh

\footnotetext{
${ }^{16}$ Abdurrahman Wahid, Merumuskan Hubungan Ideologi Nasional dan Agama, h. 71.

17 Barda Nawawi Arief, Beberapa Aspek Pengembangan Ilmu Hukum Pidana: Menyongsong Generasi Baru Hukum Pidana Indonesia, (Semarang: PustakaMagister, 2011), h. 35.

18 Lihat M. Akil Mochtar, "Visi Pembangunan Sistem Hukum Indonesia”, aksespada 4 Pebruari 2013darihttp://www. akilmochtar.com/wp-content/uploads/2011/06/

Visi_Pembangunan Sistem_Hukum_Indonesia_akil1. pdf276 Al-Tahrir, Vol. 13, No. 2 November 2013, h. 273-29 $\overline{6}$.

19 Sularno, "Syari'at Islam dan Upaya pembentukan Hukum Positif dilndonesia", diakses pada 05 Oktober 2012, dari http:// journal.uii.ac.id/index.php/JHI/article/view File/245/240.
} 
pada masa tersebut. Pernyataan di atas dapat diterima karena sesuai dengan rumusan Garisgariss Besar Haluan Negara tahun 1999-2004 berganti Program Pembangunan Nasional selaras Undang-Undang Nomor 12 Tahun 2011 tentang Pembentukan Peraturan Perundang-undangan, khususnya Pasal 18 yang menjelaskan materi undang-undang perlu dan hendaknya dirancang bangun sesuai dengan aspirasi dan kebutuhan hukum masyarakat. ${ }^{20}$ Atas perihal tersebut diperlukan antara lain suatu reformasi bermazhab secara eklektis dengan memilih sumbersumber sesuai dengan perkembangan historis dan metodologi studi agama-hukum Islam, seperti ljtihad, ljma, Qiyas, dan lainnya. Hal itu sesuai sosio-kultur yang berkembang serta strategi tertentu sesuai studi keislaman kontemporer (eklektisisme).

Pemikiran Gus Dur tersebut tampaknya ingin menegaskan kepada khalayak bahwa tugas utama Islam adalah mengembangkan etika sosial, yang memungkinkan bagi tercapainya kesejahteraan kehidupan umat manusia, baik melalui bentuk masyarakat yang bernama negara nasional maupun di luarnya. Kelahiran Forum Demokrasi (Fordem), menurut Gus Dur merupakan perwujudan dari rasa keprihatinan atas munculnya berbagai isu sektarianisme dan primordialisme, yang gejalanya ditimbulkan akibat kurangnya kebebasan dan tidak adanya nilai-nilai demokrasi yang memadai dalam kehidupan bermasyarakat dan bernegara.

Pemikiran Gus Dur dan Hasyim Muzadi yang akan diuraikan di bawah nanti merupakan masalah yang krusial. Contoh yang terjadi di Indonesia tentang hubungan agama dan negara yang selalu diperdebatkan dalam konteks Rechtsstaat dan Konstitusionalisme. Adanya rechtsstaat yang berkaitan dengan korupsi, kekerasan, narkoba, penistaan agama, dan lain-lain. Oleh karena itu, guna menghindari maraknya berbagai kasus yang terjadi di Indonesia, diperlukan adanya konsep rechtsstaat atau negara hukum dan konstitualisme dalam pemikiran Gus Dur dan Hasyim Muzadi, yang bisa diimplementasikan dalam hukum Islam di Indonesia.

${ }^{20}$ Ratno Lukito, Hukum Sakral dan Hukum Sekuler: Studi Tentang Konflik danResolusi dalam Sistem Hukum Indonesia (Jakarta: Alvabet, 2012), h. 291-299.
Gagasan tentang negara hukum tercantum di dalam Undang-Undang Dasar Negara Republik Indonesia Tahun 1945 (selanjutnya ditulis: UUD 1945), yang menjelaskan bahwa negara Indonesia berdasarkan atas hukum (rechtsstaat), tidak berdasarkan atas kekuasaan belaka (machstaat). Oleh karena itu, negara tidak boleh melaksanakan aktivitasnya atas dasar kekuasaan belaka, tetapi harus berdasarkan pada hukum ${ }^{21}$. Selanjutnya dalam UUD 1945 tersebut dinyatakan bahwa pemerintah berdasarkan atas sistem konstitusional (hukum dasar) tidak bersifat (absolutisme) kekuasaan yang terbatas, karena kekuasaan eksekutif dan administrasi di Indonesia berada dalam satu tangan, yaitu ada pada presiden. Artinya, administrasi dalam menjalankan tugasnya dibatasi oleh peraturan perundang-undangan.

Dalam pemikiran hukum Islam, penerapan prinsip-prinsip hukum tata negara Islam hendaknya juga mengacu kepada kaidah-kidah hukum Islam, yakni

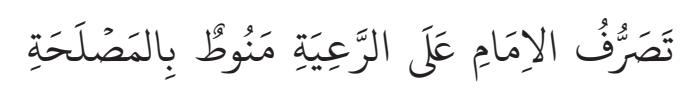
"Tindakan imam terhadap rakyatnya harus dikaitkan dengan kemaslahatan".

Kaidah tersebut didukung oleh kaidah "perbuatan yang mencakup kepentingan orang lain lebih utama daripada hanya kepentingan sendiri" (al-muta'addi afdhâl min al-qashîri). Sehingga tujuan majelis syura' dalam hukum tata negara Islam hendaknya mengacu kepada kaidah hukum "apa-apa yang tidak dapat diambil seluruhnya maka jangan ditinggalkan seluruhnya".

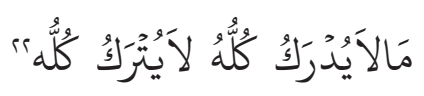

Berdasarkan kaidah tersebut, setiap orang adalah pemimpin yang memiliki hak dan kewajiban yang sama. Tetapi hal itu hendaknya bertujuan

${ }^{21}$ Likadja, Jeffry Alexander Ch, "Memaknai 'Hukum Negara (Law Through State)' dalam Bingkai 'Negara Hukum (Rechstaat)', Jurnal Hasanuddin Law Review, Vol. 1, No. 1, April 2015. http://pasca.unhas.ac.id/ojs/index.php/halrev/article/ view/41/40, diakses 20 April 2018.

${ }_{22}$ Mukhlish Usman, Kaidah-kaidah Ushuliyah dan Fiqhiyyah,(Jakarta: Gema Insani Press, 2000); Asjmuni Rahman, Kaidah-kaidah Fikih, (Qawa'id al-Fiqhiyyah), (Jakarta: Bulan Bintang, 1976). Lihat pula dalam Kitab Tabshirat al-Ahkâm, Juz I, hlm.106-108 yang dikutip oleh Abdul Karim Zaidan, Nizhâm al-Qadhâ' fî al-Syarî'ah al-Islâmiyah, (Bagdad: Matba'at al-'Ayni, 1983), h. 129. 
untuk kemaslahatan umum (maslahat al-'ammah).23

Menurut pandangan Muhammad Tahir Azhari, ${ }^{24}$ terdapat lima konsep rechtsstaat yang memiliki muatan pokok sebagaimana berikut ini. Pertama, negara hukum menurut Alquran dan Sunnah. Azhari cenderung menggunakan istilah nomokrasi Islam. Malcolm H. Kerr dan Madjid Khadduri juga menggunakan istilah nomokrasi dari sudut Islam. Untuk membedakan konsep ini dengan konsep negara sekuler atau negara hukum menurut konsep Barat, ia berpendapat istilah nomokrasi Islam lebih tepat dan lebih memperhatikan kaitan nomokrasi dengan hukum Islam. Kedua, negara hukum menurut konsep Eropa Kontinental yang dinamakan dengan rechtsstaat. Model negara hukum ini diterapkan, misalnya di Belanda, Jerman, dan Perancis. Ketiga, konsep Rule of law yang diterapkan di negaranegara Anglo Saxon, antara lain Inggris dan Amerika Serikat. Ketiga, konsep yang disebut socialist legality yang diterapkan antara lain Uni Soviet sebagai negara komunis. Keempat, konsep negara hukum Pancasila.

Dilihat dari sejarah, negara hukum adalah suatu doktrin dalam ilmu hukum yang muncul sejak zaman Yunani Kuno. ${ }^{25}$ Doktrin itu berkembang pesat pada abad ke-19 di Eropa, ber-

${ }^{23}$ A. Wahab Afif, Maslahat al-Ummah: Suatu Pendekatan Menuju Mayarakt Muslim Moderat, Orasi Penganugrahan Gelar Doktor Honoris Causa IImu Perbandingan Madzhab \& Bimbingan Masyarakat Islam, Bandung, 7 Agustus 2010, (Bandung: Universitas Islam Negeri Bandung), h. 14.

${ }^{24}$ Muhammad Tahir Azhary, Suatu Studi tentang Prinsipprinsipnya Dilihat dari Segi Hukum Islam dan Implementasinya pada Periode Negara Hukum Madinah dan Masa Kini, (Jakarta: Bulan Bintang, 1991), h. 63.

${ }^{25}$ Pada masa Yunani Kuno pemikiran tentang negara hukum dikembangkan oleh para filusuf besar Yunani Kuno, seperti Plato (429-347 SM) dan Aristoteles (384-322 SM). Secara embrionik, gagasan negara hukum telah dikemukakan oleh Plato dan Aristoteles, ketika ia mengintroduksi konsep Nomoi, sebagai karya tulis ketiga yang dibuat di usia tuanya. Sementara itu, dalam dua tulisan pertama, Politeia dan Politicos, belum muncul istilah negara hukum. Namun dalam Nomoi, Plato menguraikan bentuk-bentuk pemerintahan yang mungkin dijalankan. Plato mengemukakan bahwa penyelenggaraan negara yang baik ialah yang didasarkan pada pengaturan (hukum) yang baik. Gagasan Plato ditulis dalam buku Politica. Plato banyak mengemukakan penjelasan tentang konsep nomoi sebagai cikal-bakal pemikiran tentang negara hukum. Menurut Plato, pada dasarnya ada dua macam pemerintahan yang dapat diselenggarakan, yaitu pemerintahan yang dibentuk melalui jalan hukum dan pemerintahan yang terbentuk tidak melalui jalan hukum. Lihat dalam Budiono Kusumohamidjojo, Filsafat Hukum: Problemtika Ketertiban yang Adil, (Jakarta: Grasindo, 2004), h. 36-37. samaan dengan kelahiran negara konstitusi dan demokrasi. Secara sederhana pengertian negara hukum adalah negara yang penyelenggaraan kekuasaan pemerintahannya didasarkan atas hukum. Di negara yang berdasarkan atas hukum, ${ }^{26}$ negara termasuk di dalamnya pemerintah dan lembaga-lembaga lain dalam melaksanakan tindakan apapun harus dilandasi oleh hukum dan dapat dipertanggungjawabkan secara hukum. ${ }^{27}$

Masalah relasi agama dengan negara merupakan salah satu hal yang penting dalam pemikiran Gus Dur. Oleh karena itu banyak orang yang melakukan review terhadap pemikirannya. Secara garis besar bisa dikatakan bahwa arus pemikiran Gus Dur mengenai relasi agama dan negara dapat dikategorikan sebagai pemikiran yang "sekularistik", yaitu pemisahan antara agama dan negara. Menurut Gus Dur, Islam tidak pernah menganjurkan pembentukan negara Islam. Islam hanyalah sebagai jalan hidup (way of life) tidak memiliki konsep yang jelas tentang negara. ${ }^{28}$ Baginya Islam adalah agama yang penuh dengan kasih sayang, toleran, dan keadilan.

Sementara itu, menurut pemikiran $\mathrm{K}$. $\mathrm{H}$. Hasyim Muzadi, ada hubungan antara agama dengan negara, sekali pun sebuah negara berasaskan Islam atau berbentuk negara Islam, tidak secara otomatis nilai-nilai Islam dapat dilaksnakan secara baik dalam sistem kenegaraan. Hasyim Muzadi menjelaskan bahwa Pancasila lah sebagai dasar negara Indonesia dan Pancasila mampu sebagai pemersatu bangsa yang plural, serta Pancasila adalah pilihan yang cerdas untuk menjaga keutuhan bangsa Indonesia. Walau tidak berdasarkan agama secara formal, menurut Hasyim, Indonesia bukanlah negara sekuler. Indonesia adalah negara yang berketuhanan

${ }^{26}$ Gagasan tentang negara hukum yang telah dikembangkan oleh Plato, Aristoteles, John Lock, Montesquieu, dan lainnya, masih bersifat samar-samar, dan tenggelam dalam waktu yang sangat panjang.Kemudian muncul kembali secara lebih eksplisit pada abad XIX, dengan munculnya konsep rechsstaat yang dikembangkan oleh Frederich Julius Stahl di Eropa Continental yang diilhami oleh pemikiran Immanuel Kant. Lihat: O. Notohamidjojo, Makna Negara Hukum bagi Pembaharuan Negara dan Wibawa Hukum bagi Pembaharuan Masyarakat di Indonesia, (Jakarta: Badan Penerbit Kristen, 1970), h. 21.

${ }^{27}$ M. Tahir Azhary, Negara Hukum, (Jakarta: Bulan Bintang, 1992), h. 73-74.

28 Abdurrahman Wahid,Islamku Islam Anda Islam Kita,(Jakarta: The Wahid Institute, 2006), h. 81. 
Yang Maha Esa, karena itu negara tidak hanya saja wajib memberikan perlindungan tetapi juga mengatur hubungan umat beragama tanpa melakukan intervensi terhadap ajaran teologis setiap agama. Hasyim mengatakan, bahwa perilaku hubungan antara agama dan negara tidak dapat terpisahkan. Menurut paham teokrasi, agama dan negara dipahami sebagai dua hal yang tidak dapat dipisahkan, dijalankan berdasarkan firman-firman Tuhan, sehingga segala tata kehidupan masyarakat, bangsa dan negara dilakukan berdasarkan perintah Tuhan. Dengan demikian, urusan kenegaraan atau politik, menurut paham teoraksi merupakan manifestasi dari perintah Tuhan dalam kehidupan manusia. ${ }^{29}$

\section{Kontribusi Pemikiran Abdurrahman Wahid dan Hasyim Muzadi}

Kontribusi pemikiran Abdurrahman Wahid (Gus Dur) dan Hasyim Muzadi sebagai berikut. Abdurrahman Wahid ${ }^{30}$ berpendapat bahwa, dalam Islam, negara itu adalah hukum dan sama sekali tak memiliki bentuk negara. Yang penting di dalam Islam adalah etika kemasyarakatan dan komunitas. Alasannya, Islam tidak mengenal konsep pemerintahan yang definitif. Bahkan dalam persoalan yang paling pokok, yakni suksesi kekuasaan, menurut Abdurrahman Wahid ternyata Islam tidak konsisten. Terkadang memakai istiskhlaf, bai'at atau ahl al-hall wa al-'aqd. Padahal persoalan suksesi adalah masalah yang cukup urgen dalam masalah kenegaraan. la memberikan catatan jika memang Islam mempunyai konsep tentu tidak terjadi demikian. Bagi Gus Dur, Islam memang sengaja tidak mengatur konsep kenegaraan agar ia bisa diterima oleh semua entitas budaya. Menurut Gus Dur, yang ada hanyalah komunitas agama (kuntum khayr ummatin ukhrijat li-al-nâs). Jadi, khaira ummatin bukan khaira daulatin atau khaira jumhuriyatin apalagi khaira mamlakatin.Di abad modern ini, mau tidak mau Islam harus mau berinteraksi dengan sederetan fenomena yang secara global merupakan nation state. ${ }^{31}$ Tidak mudah bagi kaum

\footnotetext{
29 Deliar Noer, Gerakan Modern Islamdi Indonesia 19001942, (Jakarta: LP3ES, 1988), h. 54

$3^{30}$ Lihat Ali Masykur Musa, Pemikiran dan Sikap Politik Gus Dur, (Jakarta: Erlangga,2010), h. 94.

${ }^{31}$ M. Masyhur Amin, NU dan ljtihad Politik Kenegaraannya,
}

muslimin untuk mencernakan keharusan historis dalam beriteraksi dengan fenomena global itu. Pemikiran Gus Dur tersebut, tampaknya ingin menegaskan kepada khalayak bahwa tugas utama Islam adalah mengembangkan etika sosial ${ }^{32}$ yang memungkinkan bagi tercapainya kesejahteraan kehidupan umat manusia, baik melalui bentuk masyarakat yang bernama negara nasional maupun di luarnya. Selain itu, fungsionalisasi etika sosial dapat saja berbentuk pengundangan melalui hukum positif, maupun sekedar melalui penyadaran masyarakat tentang pentingnya pelaksanaan ajaran agama dalam kehidupan nyata. Dengan demikian, baik pandangan Gus Dur lebih menekankan agar nilai-nilai Islam dapat difungsikan sepenuhnya ke dalam sebuah masyarakat bangsa terlepas dari bentuk negara yang digunakan.

Kemudian dalam konteks pluralisme, Abdurrahman Wahid yang melihat hubungan antara Islam dengan pluralisme dalam konsteks manifestasi universalisme dan kosmopolitanisme ajaran Islam.Menurut Gus Dur, ajaran yang dengan sempurna menampilkan universalisme Islam adalah 5 (lima) jaminan dasar yang diberikan Islam kepada warga masyarakat, baik secara perorangan maupun sebagai kelompok. Kelima jaminan dasar tersebut, menurut pandangan Gus Dur telah tersebar dalam literatur hukum agama (al-kutub al-fiqhiyyah) lama, yang terdiri dari: (a) keselamatan fisik warga masyarakat dari tindakan badani di luar ketentuan hukum; (b) keselamatan keyakinan agama masing-masing tanpa ada paksaan untuk berpindah agama; (c) keselamatan keluarga dan keturunan; (d) keselamatan harta benda dan milik pribadi di luar prosedur hukum; dan (e) keselamatan profesi.

Pemikiran Abdurrahman Wahid tersebut, tampaknya ingin menegaskan kepada khalayak bahwa tugas utama Islam adalah mengembangkan etika sosial yang memungkinkan bagi tercapainya kesejahteraan kehidupan umat manusia, baik melalui bentuk masyarakat yang bernama

\footnotetext{
(Yogyakarta: al-Amin Press, 1996), h. 94-120.

32 Abdurrahman Wahid, "Universalisme Islam dan Kosmopolitanisme Peradaban Islam", dalam Budhy MunawarRachman (ed), Kontekstualisasi Doktrin Islam dalam Sejarah, (Jakarta: Paramadina), h. 545-552.
} 
negara nasional maupun di luarnya. Selain itu, fungsionalisasi etika sosial dapat saja berbentuk pengundangan melalui hukum positif, maupun sekedar melalui penyadaran masyarakat tentang pentingnya pelaksanaan ajaran agama dalam kehidupan nyata. Dengan demikian, pandangan Abdurrahman Wahid lebih menekankan agar nilai-nilai Islam dapat difungsikan sepenuhnya ke dalam sebuah masyarakat bangsa terlepas dari bentuk negara yang digunakan.Muhammad A. S. Hikam mengatakan bahwa Gus Dur adalah sosok yang sangat kompleks sehingga melakukan kajian atas wawasan intelektualnya merupakan kegiatan yang tidak sederhana, sangat berlikuliku, sehingga membutuhkan kecermatan yang sangat hati-hati. Setidaknya ada tiga kata kunci atau cara untuk memahami pemikirannya, yaitu liberalisme, demokrasi, dan universalisme. Berbicara tentang kesempurnaan Islam, seperti ditegaskan dalam Q. S. al-Maidah [5]: 3 yang artinya; "Pada hari ini telah Aku sempurnakan untuk kamu agamamu, dan telah Aku cukupkan kepadamu nikmat-Ku, dan telah Aku ridhai Islam menjadi agama bagimu". Abdurrahman Wahid pun sangat meyakini kebenaran ayat ini. Namun, berbeda dengan pandangan ulama pada umumnya yang mengira segala sesuatu kepentingan hidup sudah lengkap dalam Alquran baik secara eksplisit maupun secara implisit. Kelemahan pandangan ini adalah kenyataan bahwa ayat tersebut tidak melarang pengembangan wawasan baru secara terus-menerus dalam Islam. Hakikat kesempurnaan dan kelengkapan Islam justru terletak pada potensinya menampung masukanmasukan secara kontinuitas, sebagai bagian dari proses penghadapan Islam pada tuntutan keadaan zaman. ${ }^{33}$

Maka, kontribusi pemikiran Gus Dur tampak pada pemahaman keislamannya. Akan tetapi, konteks pemikiran Gus Dur tidak terlepas dari suatu kenyataan sosial masyarakat Indonesia. Ada tiga hal yang harus diperhatikan sebagai berikut.

Pertama, perdebatan tentang perlunya memasukkan Islam dalam konstitusi telah terjadi sejak awal kemerdekaan Indonesia. Kenyataan

${ }^{33}$ Mujamil Qomar, NU "Liberal" dari Tradisionalisme Ahlus Sunnah Wal Jamaah ke Universalisme Islam, (Bandung: Mizan, 2002), h. 169. bahwa Pancasila diterima sebagai dasar negara tidak meniadakan keinginan orang-orang tertentu untuk menjadikan Islam sebagai dasar negara. Meskipun tidak menampakkan diri dalam cara yang terang-terangan, wacana untuk menjadikan Islam sebagai dasar negara tetaplah suatu wacana yang ramai diperbincangkan.

Kedua, sebagai negara demokratis, Indonesia perlu merumuskan suatu relasi yang jelas antara sistem demokrasi dengan keberadaan agamaagama. Hal ini, terjadi karena sebagai negara yang bukan negara agama dan bukan negara sekuler,masyarakat Indonesia berada di antara dua konsep yang membentuk keindonesiaan. Oleh karena itu, sebagaimana demokrasi memberi ruang pada agama, agama pun harus menemukan peran yang tepat dalam sistem demokrasi. Berkenaan dengan demokrasi ini, pendapat Gus Dur yang dikutip Wardatul Jannah ${ }^{34}$ dalam Jurnal JOM FISIP dijelaskan bahwa ada tiga hal pokok demokrasi yaitu, (1) kebebasan, (2) keadilan, dan (3) musyawarah. Kebebasan adalah kebebasan individu sebagai warga negara dan hak kolektif dari masyarakat. Keadilan merupakan landasan demokrasi.Dalam kata lain, terbuka peluang bagi semua komponen masyarakat untuk mengatur hidupnya sesuai kehendak masing-masing. Setiap orang memiliki hak dan kesempatan untuk mengatur hidup dan kehidupannya sehingga harus diberi jalan yang mudah dan tidak dipersulit, seperti beberapa kasus yang terjadi pada saat Orde Baru. Pokok demokrasi yang ketiga adalah musyawarah. Artinya, bentuk atau cara memelihara kebebasan dan memperjuangkan keadilan itu harus ditempuh lewat jalur permusyawaratan. Gagasan demokratisasi Gus Dur telah dilempar ke publik jauh sebelum menjadi presiden RI.

Ketiga, salah satu ciri masyarakat Indonesia adalah adanya budaya-budaya lokal. Tak jarang masuk-masuknya agama-agama nonlokal telah menimbulkan suatu pertanyaan akan eksistensi budaya-budaya itu dalam agama. Hal mengenai penerimaan budaya tertentu atau penolakan

34 Jannah, Wirdatul, "Pemikiran Abdurrahman Wahid tentang Demokrasi Pluralistik dan Pengaruhnya di Indonesia", Jurnal Online Mahasiswa Fakultas Ilmu Sosial dan Politik Universitas Riau, Vol. 5, Edisi I, Januari-Juni 2018, https:// jom.unri.ac.id/index.php/JOMFSIP/article/view/19235/18592, diakses 20 April 2018 
budaya lainnya tentu perlu memiliki dasar yang jelas. Selain itu, perkembangan sains telah membentuk kebudayaan manusia yang baru.

Ketiga konteks di atas mengantarkan kita kepada beberapa pokok pemikiran Gus Dur. Adapun pokok-pokok pemikiran Gus Dur di antaranya sebagai berikut. Sistem pemerintahan Islam tidak diperlukan di Indonesia. Pemikiran ini merupakan sebuah kesimpulan dari perdebatan tentang perlu tidaknya sebuah sistem Islam. Gus Dur mengangkat hal mendasar yaitu bahwa berkaitan dengan perlu tidaknya sebuah sistem pemerintahan Islam, terjadi perbedaan penafsiran terhadap ayat Alquran yang berbunyi: "Masukilah kalian ke dalam Islam (kedamaian) secara penuh (udkhulû fî al-silmi kaffah)" (Q.S. al-Baqarah [2]: 208). Menurut Gus Dur, orang-orang yang menyukai formalisasi menerjemahkan kata "alsilmi" menjadi "Islam" maka, menuntut ada sistem Islami yang dapat mewakili aspirasi kaum Muslimin seluruhnya. Sedangkan orang-orang lain menerjemahkankata itu menjadi "kedamaian" sehingga mereka tidak melihat perlunya hal itu dijabarkan dalam sebuah sistem tertentu termasuk sistem Islami. ${ }^{35}$

Menurut Gus Dur, adanya sistem Islami menjadikan umat yang bukan beragama Islam menjadi warga dunia kelas dua. Selain itu, hal itu juga berpengaruh pada orang-orang Islam yang dianggap kurang kualitas keislamannya dibandingkan dengan mereka yang menjalankan ajaran Islam secara penuh atau Muslim santri. ${ }^{36}$ Padahal, dalam Alquran terdapat ayat "Tiadalah Kuutus Engkau Ya Muhammad, kecuali sebagai pembawa persaudaraan bagi umat manusia (Q.S. al-Anbiya [21]: 107).

\section{Kontribusi Pemikiran Hasyim Muzadi}

Sementara kontribusi pemikiran Hasyim Muzadi tentang sebuah negara berazaskan Islam atau berbentuk negara Islam, tidak secara otomatis nilai-nilai Islam dapat dilaksanakan secara baik dalam sistem kenegaraan. Dengan tema "Membumikan Ajaran Islam Rahmatan Lil

${ }^{35}$ Abdurrahman Wahid, Islamku Islam Anda Islam Kita: Agama Masyarakat Negara Demokrasi, (Jakarta: The Wahid Institute, 2006), h. 3-4.

${ }^{36}$ Abdurrahman Wahid, Islamku Islam Anda Islam..., h. 4-12.
'Alamin di Bumi Nusantara dalam Membangun Harmonitas Kehidupan Berbangsa dan Bernegara", Hasyim Muzadi menjelaskan bahwa Pancasila sebagai dasar negara Indonesia dan Pancasila mampu sebagai pemersatu bangsa yang plural, serta Pancasila adalah pilihan yang cerdas untuk menjaga keutuhan bangsa Indonesia.Walau tidak berdasarkan agama secara formal, menurut Hasyim, Indonesia bukanlah negara sekuler, Indonesia adalah negara yang berketuhanan Yang Maha Esa, karena itu negara tidak hanya saja wajib memberikan perlindungan (proteksi) tetapi juga mengatur hubungan umat beragama tanpa melakukan intervensi terhadap ajaran teologis setiap agama.

Agama akan terlindungi oleh negara. Dijelaskan Hasyim bahwa human rights (HAM) lahir pada tahun 1948, bahkan di negara Eropa yang ketika itu sekuler. HAM tidak mendapatkan hambatan karena tidak adanya tata nilai di negara tersebut. HAM bisa berjalan dengan humanis tanpa harus membentur teologi, ritual, dan tata nilai atau local wisdom (kearifan lokal). Menurut Hasyim, sebuah negara sekuler hampir tidak memberi ruang bagi agama baik formalitasnya maupun subtansinya dan tidak memberi ruang dalam setiap produk hukum dan penyelenggaraan negara.Karena itu, seringkali sebuah negara sekuler menerapkan aturan hukum dan perundangan yang justru bertentangan dengan ajaran-ajaran agama yang ada di negara itu, misalnya dengan mengatasnamakan keadilan hak asasi manusia. Human rights yang dibawa ke Indonesia sebenarnya sudah ada pada tata nilai atau local wisdom di Indonesia, tetapi menurut Hasyim seperti dilansir laman resmi Kementerian Agama RI,ketika ada human rights yang baru dan kemudian menabrak berbagai macam tata nilai yang ada di Indoensia, maka akan menjadi masalah. Hasyim menambahkan bahwa human rights harus selaras dengan harmoni.Kita memiliki kebhinekaan tapi harus tunggal Ika. Kita tidak punya keekaan, tetapi yang ada adalah kebhinekaan. Oleh karena itu, human rights tidak boleh merusak kebhinekaan, tetapi harus ada keseimbangan dan HAM harus selaras dengan harmoni kemanusiaan dalam filosofi negara Pancasila. Hasyim yang merupakan mantan 
Ketua Umum PBNU juga mengatakan bahwa perilaku hubungan antara agama dan negara tidak dapat terpisahkan. Moderasi merupakan salah satu jalan bagaimana kita tidak menghilangkan jati diri beragama dan tidak menjadi masalah bagi negara yang Berbhineka Tunggal Ika. Dengan kata lain, menurut Dahlan ${ }^{37}$, moderasi agama dan negara sebagaimana digagas oleh Hasyim Muzadi itu menyangkut bagaimana tata hubungan yang seimbang antara hukum Islam dengan negara, yakni bagaimana hukum Islam dilindungi negara, dan negara terinspirasi oleh hukum hukum Islam dengan tetap dalam bingkai nasionalisme, pluralitas dan Negara Kesatuan Republik Indonesia (NKRI), disamping kunjungan lintas agama.

Kemudian Hasyim Muzadi mengatakan bahwa terlepas dari keragaman yang mungkin bisa dijadikan sebagai faktor penghambat unifikasi, fenomena tersebut mengindikasikan bahwa perbedaan pemikiran yang terjadi sampai pada abad pertengahan dapat dipandang sebagai usaha sungguh-sungguh umat Islam untuk menjaga universalitas ajaran agamanya. Dalam hal ini, pilihan yang tersedia hanya dua; Pertama, membakukan agama sebagaimana yang tercantum dalam teks-teks suci, serta membiarkannya berjalan pada suatu garis penafsiran yang linier tanpa interpretasi ulang, meskipun ia bersentuhan dengan kompleksitas persoalan kemanusiaan, yang berarti menutup rapat-rapat pintu agama dari upaya kontekstualisasi yang lebih berkesadaran sejarah, ini kata Hasyim tidak dibenarkan sebab kekhawatiran berlebihan bahwa reinterpretasi atau kontekstualisasi akan dapat menodai sakralitas agama..$^{38}$ Kedua, melakukan dinamisasi atas ajaran-ajarannya yang mentolerir upaya interpretasi agama dalam rangka mencari titik relevansinya dengan kebutuhan zaman yang terus berkembang. Dalam hal ini, Hasyim memihak pada pilihan yang kedua, karena lebih memberi peluang kemajuan bagi Islam meski belakangnya juga nyimpan resiko yang masih bisa diatasi,

${ }^{37}$ Dahlan, Moh., "Moderasi Hukum Islam dalam Pemikiran Ahmad Hasyim Muzadi" Al-Ihkam: Jurnal Hukum dan Pranata Sosial, Vol 11, No 2, 2016. http://ejournal.stainpamekasan.ac.id/ index.php/alihkam/article/view/1039/809, diakses 20 April 2018.

${ }_{38}$ Hasyim Muzadi, Nahdlatul Ulama di Tengah Agenda Peersoalan Bangsa, (Jakarta: Logos Wacana Ilmu, 1999), h. 129-130. daripada mengekang progretivitas penafsiran yang justru menyebabkan ajaran agama menjadi beku dan sulit berkembang.

Bagi NU, nilai-nilai agama boleh dibiarkan terserap dalam organisasi negara tanpa harus memikirkan apakah label agama dicantumkan atau tidak. Karena pada dasarnya, inti ajaran Islam beserta nilai-nilai kemanusiaan yang dibelanya dipandang telah dimanifetasikan dalam sila-sila Pancasila. Islam dapat menerima butir-butir yang dicantumkan dalam Pancasila, selain juga didasari pertimbangan bahwa Pancasila sebenarnya dirumuskan oleh tokoh-tokoh Islam.

Maka, keputusan-keputusan negara baik bersifat filosofi seperti Pancasila atau kontruksi hukum seperti UUD 1945 atau tata laksana hukum seperti;Pandangan Hasyim Muzadi bahwa Perundangan dan Peraturan-peraturan negara, cukup memadai sebagai humanitas dan tidak bertentangan dengan teologi maupun ritual kita. Dalam pandangan Muzadi, sudah dijelaskan di dalam membuat Undang-Undang Anti Korupsi, maka orang Islam tidak usah ngotot harus ada undang-undang Islam anti korupsi, karena anti korupsi itu sudah ajaran Islam dan agama lain pun tidak perlu mengatakan harus ada undang-undang agama lain anti korupsi, karena anti korupsi sudah ajaran agama yang lain juga. Maka, titik temu ini yang harus kita pertahankan, titik temu dari semua ajaran agama yang melarang akan korupsi harus dipertahankan sebaik-baiknya sehingga didalam kebhinekaan bernegara menjadi nyata dalam pemikiran kita bersama, tegas Hasyim. "Maka tidak dipungkiri kerukunan umat beragama akan lestari dan terpelihara baik di Indonesia, manakala pemikiran-pemikiran tersebut berangkat dari pemikiran agama masing-masing dan tidak hanya berlaku pada satu saat saja atau karena politik-politik praktis yang berkepentingan di belakangnya," menurut Hasyim.

Kontribusi Hasyim dalan hubungan agama dan negara ketika ijtihad politik pria berusia 60 tahun ini yang menerima lamaran PDI Perjuangan untuk menjadi Calon Wakil Presiden (Cawapres) di Pemilu 2004, yang merupakan bagian dari sosok dirinya yang moderat. "Saya ingin menyatukan antara kaum nasionalis dan agama", ketika berorasi dalam deklarasi pasangan capres dan 
cawapres Mega-Hasyim. Maka, titik temu ini yang harus kita pertahankan, titik temu dari semua ajaran agama yang melarang akan korupsi harus dipertahankan sebaik-baiknya sehingga di dalam kebhinekaan bernegara menjadi nyata dalam pemikiran kita bersama. "Maka tidak dipungkiri kerukunan umat beragama akan lestari dan terpelihara baik di Indonesia, manakala pemikiranpemikiran tersebut berangkat dari pemikiran agama masing-masing dan tidak hanya berlaku pada satu saat saja atau karena politik-politik praktis yang berkepentingan di belakangnya.

Sementara implikasi sikap Hasyim Muzadi terhadap adanya hubungan agama dengan negara terwujud dalam istilah rahmatan lil 'alamin yang diterjemahkan ke dalam sikap tawassuth, tawazun, tasâmuh, dan i'tidal dalam perspektif empiris dengan tema adalah "Membantu Mengatasi Krisis dan Menjaga Keutuhan NKRI". Peran yang dilihat oleh antropolog Clifford Geertz ini, menggambarkan posisi kiai yang tidak terbatas pada pengajar agama, tetapi juga penyaring budaya (dari luar), plus komunikator budaya, yang berfungsi sebagai pendamping atas beberapa persoalan kultural masyarakat, semisal konsultasi nikah, perdagangan, waris, dan sebagainya. Hal ini yang membuahkan kharisma, sehingga masukan dan ajaran kiai, diterima masyarakat, sebagai representasi dari “jawaban Tuhan”. Hasyim Muzadi mengatakan bahwa hakikat semua ajaran agama mengajarkan perdamaian, kesejahteraan, kelemahlembutan dan toleransi.

Kemudian berkaitan dengan implikasi pandangan Hasyim tentang hukum Islam bahwa istilah rahmatan lil 'alamin yang diterjemahkan ke dalam sikap tawassuth dan itidal terhadap hubungan agama dan negara dalam perspektif empiris adalah "Membantu Mengatasi Krisis dan Menjaga Keutuhan NKRI"39. Tanpa menarik diri dari garis politik kekuasaan, NU tidak akan memperoleh legitimasi moral untuk memosisikan dan memungsikan dirinya kembali sebagai reprensentasi civil society. Menyangkut

39 Rasyid, Muhammad Makmun, "Islam Rahmatan Lil Alamin Perspektif K.H. Hasyim Muzadi”, Episteme: Jurnal Pengembangan Ilmu Keislaman, Vol 11, No 1, 2016, h. 105 http://ejournal.iain-tulungagung.ac.id/index.php/epis/article/ view/189/134, diakses 21 April 2018. pernyataannya agar dilakukan perenungan kembali mengenai amandemen UUD 1945, Kiai Hasyim Muzadi dalam wawancaranya menyatakan bahwa "perlunya review apakah amandemen itu memang kebutuhan yang mendesak dan tidak terelakkan apakah baru merupakan:kemauankemauan yang diakomodasi karena di setiap negara pasti dalam kurun tertentu ada perubahan tapi sebatas kebutuhan mendesak atau lebih dari itu. Misalnya, UUD 1945 dianggap terlalu ketat sehingga kekuasaan utama berada di bawah Eksekutif dan yang lain-lain itu menjadi di bawah eksekutif kemudian menjadikan pemerintahan yang sentralistik, kemudian dikritisi." Berhubungan dengan syariat Islam, yakni dengan maraknya Peraturan Daerah (Perda) yang bernuasa. Syari'ah, Hasyim Muzadi dalam wawancaranya rnengatakan bahwa, "syariat Islam seharusnya ada dalam konteks civil society bukan nation state." Ada kekhawatiran darinya bahwa formalisasi syariat Islam dalam Perda hanya akan memicu perpecahan bangsa. Suatu syariat harus ada dalam dimensi kemasyarakatan dan tidak dinegarakan. Perlu dicatat syariat disini bukan semata syariat Islam, karena seluruh agama memiliki syariat. Adapun maksud dinegarakan tersebut adalah dijadikan hukum positif. Semestinya sumbangan agama kepada negara dalam tataran nilai, bukan syariat.Kalau formalisasi yang dijadikan dasar hukum positif, negara bisa pecah. Contohnya perda anti korupsi, judi, dan pelacuran peneliti yakin semua agama melarangnya. Tetapi, jika itu disebut sebagai undang-undang Islam antikorupsi, orang beragama lain pasti marah. Jadi, yang diperlukan adalah substansinya tanpa membawa simbol agama."

Sikap Hasyim Muzadi baik secara pribadi maupun atas nama organisasi NU, tidak menyetujui adanya formalisasi syariat agama. Syariat agama hanya sebagai suatu bentuk kebebasan dalam cakupan kemasyarakatan.Hasyim Muzadi memberikan penekanan mempertegas Khittah NU 1926 dan memberdayakan civil society, sebagai konsekuensi sikap rahmatan lil'alamin terhadap interen organisasi NU adalah dikembangkannya wawasan sikap moderat, menghargai pendapat orang, melakukan praktik-praktik musyawarah dalam setiap pengambilan keputusan organisasi. 
Terhadap jamaahnya dikembangkan sikap-sikap bertoleransi dan saling menolong pada kebaikan dalam rangka memperbaiki kualitas umat demi tegaknya izzul Islam wal-muslimîn. Pandangan Hasyim Muzadi merupakan sebuah upaya penelusuran masalah yang dihadapi NU sebagai organisasi sosial keagamaan, serta pemotretan sejumlah pandangan dan ide. Oleh karena itu,

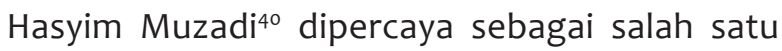
tokoh yang banyak mengetahui persolan yang dihadapi NU, baik di tingkat regional Jawa Timur maupun di level nasional. Penguasannya terhadap khazanah Islam klasik serta intensitas pergumulan intelektualnya dalam rangka merespon polemik kebangsaan melalui penalaran khas kaum santri yang tercerahkan menjadi alasan yang cukup kuat untuk dipakai sebagai bahan perenungan dalam rangka membikin sketsa sejarah masa lalu, kini, dan akan datang, yang di dalamnya mengandung pula gagasan-gagasan NU sebagai salah satu motor gerakan kultural di Indonesia demi meniti jalan panjang nan terjal menuju demokrasi yang lebih matang.

Ibn Arabi sebagaimana dimuat dalam jurnal Humanistika mengatakan bahwa keputusankeputusan negara baik bersifat filosofi seperti Pancasila atau Konstruksi Hukum seperti UUD 1945 atau Tata Laksana Hukum seperti Perundangan dan Peraturan-peraturan Negara cukup memadai sebagai humanitas dan tidak bertentangan dengan teologi maupun ritual kita ${ }^{41}$. Dalam pandangan Hasyim Muzadi, sudah dijelaskan di dalam membuat Undang-Undang Anti Korupsi, maka orang Islam tidak usah ngotot harus ada undang-undang Islam anti korupsi, karena anti korupsi itu sudah ajaran Islam dan agama lain pun tidak perlu mengatakan harus ada undang-undang agama lain anti korupsi, karena anti korupsi sudah ajaran agama yang lain juga. Adapun titik temu yang harus kita pertahankan, titik temu dari semua ajaran agama yang melarang akan korupsi harus dipertahankan sebaik-baiknya sehingga didalam kebhinekaan bernegara menjadi

${ }^{40}$ Hasyim Muzadi, Nahdlatul Ulama di Tengah Agenda Persoalan Bangsa, (Jakarta: Logos Wacana Ilmu, 1999), h. xii.

${ }^{41}$ Arabi, Ibnu, "Konstruksi Islam Rahmah li al-'Alamin K.H. Ahmad Hasyim Muzadi”, Humanistika: Jurnal Keislaman,Vol. 4, No. 1, 2018, h. 48. https://www.ejournal.inzah.ac.id/index.php/ humanistika/article/view/162/128, diakses 21 April 2018. nyata dalam pemikiran kita bersama.

Maka, tidak dipungkiri kerukunan umat beragama akan lestari dan terpelihara baik di Indonesia, manakala pemikran-pemikiran tersebut berangkat dari pemikran agama masing-masing dan tidak hanya berlaku pada satu saat saja atau karena politik-politik praktis yang berkepentingan di belakangnya. Membumikan ajaran Islam rahmatan lil 'alamin di bumi Nusantara dalam membangun harmonitas kehidupan berbangsa dan bernegara, Hasyim Muzadi menjelaskan bahwa Pancasilalah yang sebagai dasar negara Indonesia, dan Pancasila mampu sebagai pemersatu bangsa yang plural, serta Pancasila adalah pilihan yang cerdas untuk menjaga keutuhan bangsa Indonesia. Walau tidak berdasarkan agama secara formal, menurut Hasyim Muzadi, Indonesia bukanlah negara sekuler, Indonesia adalah negara yang berketuhanan Yang Maha Esa, karena itu negara tidak hanya saja wajib memberikan perlindungan (proteksi) tetapi juga mengatur hubungan umat beragama tanpa melakukan intervensi terhadap ajaran teologis setiap agama. Maka, agama akan terlindungi oleh negara.

Islam rahmatan lil 'alamin mampu membuat para pengikutnya di dalam menyampaikan ajaran atau dakwah yang penuh penuh keramahan, kedamaian dan kebijaksanaan, mudah diterima oleh masyarakat dengan sukarela tanpa perlawananan dan kekerasan. Menelaah gagasan Islam Rahmatan lil Alamin perspektif Hasyim Muzadi, merujuk kepada sumber primer, yakni Islam Rahmatan lil 'Alamin menuju keadilan dan perdamaian dunia (Perspektif Nahdatul Ulama).Islam tidak saja bersifat ko-eksistensi lintas batas, lintas agama dan suku, tetapi pro-eksistensi tentang proyeksi kehidupan yang saling bergandengan, dengan laku tindak santun, damai dan saling pengertian. $\mathrm{KH}$. Hasyim Muzadi mengatakan bahwa hakikat semua ajaran agama mengajarkan perdamaian, kesejahteraan, kelemahlembutan dan toleransi. Jika terdapat kelompok agama melakukan antidamai, anti-toleransi dan melakukan tindak kekerasan, pastikan bahwa dirinya telah membajak agama. Karena itu, agama harus dilepaskan dari setiap tindakan dan perilaku yang tidak sesuai dengan tujuan agama itu sendiri. Agama tidak dapat dijadikan alat untuk kepentingan politik 
atau ekonomi. Menciptakan perdamaian adalah kewajiban semua agama. Merebaknya Islam fobia, dikarenakan tindakan dan perbuatan segelintir orang yang mengatasnamakan Islam untuk menjustifikasi tindak kekerasannya.

\section{Penutup}

Posisi pemikiran Gus Dur dan Hasyim Muzadi di kalangan Sarjana Muslim dalam kaitannya dengan hukum Islam dapat disimpulkan sebagai berikut. Jika dibandingkan dengan beberapa pemikir muslim lainnya, peneliti berpendapat bahwa Gus Dur dapat diposisikan sebagai pemikir, muslim subtansialis, dan agamawan humanis, nasionalis, dan demokratis. Ada beberapa alasan peneliti menyebutkan demikian (1) pemikiran Gus Dur menjunjung tinggi demokrasi dan pribumisasi Islam; (2) pemikiran Gus Dur bersifat moderat dan berpengaruh terhadap adanya hubungan agama dan negara yang lebih maju di Indonesia; (3) membela HAM dan membela kaum minoritas. Sedangkan posisi Hasyim sebagai sosok kiai yang kharismatik, tokoh NU pemimpin agama yang humanis, nasionalis, dan pluralis. Alasannya pemikiran Hasyim Muzadi menjadikan Islam dalam bingkai rahmatan lil 'alamin; Islam mengatur konflik global; dan Islam telah mewujudkan masyarakat madani (civil society).

Gus Dur dan Hasyim Muzadi terbukti memberikan kontribusi bagi masa depan hubungan agama dan negara dalam hukum Islam di Indonesia. Beberapa alasan yang ingin ditampilkan peneliti adalah bahwa (a) pemikiran Gus Dur telah mampu menghadirkan keislaman yang sesuai dengan konteks Indonesia, yaitu model keislaman yang mampu memberikan respon secara adil dalam bidang hukum, politik, dan budaya Islam di Indonesia; (b) setidaknya ada tiga kata kunci atau cara untuk memahami pemikiran Gus Dur yaitu: liberalisme, demokrasi, dan universalisme. Maka, pembelaan terhadap minoritas mendapatkan perhatian yang serius. Sementara kontribusi Hasyim Muzadi dalam hubungan agama dan negara adalah (a) pemikiran Hasyim Muzadi bahwa umat Islam di Indonesia sekalipun mayoritas namun tidak pernah memaksakan Islam sebagai dasar formal negara Indonesia. (b) Islam lebih menghendaki suatu aksi yang mampu menyejahterahkan masyarakat luas tanpa sekat-sekat agama, suku, ras, sebagai realisasi dari rahmatan lil 'alamin.

\section{Pustaka Acuan}

A, S. Hikam Muhammad, "Gus Dur, Pembaharu dan Cendikiawan Kelana: Sebuah Pengantar", dalam A.S. Laksana (ed.), NU Pasca Gus Dur. Jakarta: Fatma Press, 1977.

Acton, Lord, Konsep Negara Hukum, petikan artikel yang dipublikasikan dalam http://kgsc. wordpress.com/2009/07/11/ perkembangankonsep-negara-hukum/ diakses tanggal 12 Agustus 2012.

Afif, A. Wahab, Maslahat al-Ummah: Suatu Pendekatan Menuju Masyarakat Muslim Moderat, Orasi Penganugrahan Gelar Doktor Honoris Causa Ilmu Perbandingan Madzhab \& Bimbingan Masyarakat Islam, tanggal 7 Agustus 2010 di Bandung, 2010.

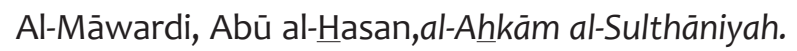
Bayrūt: Dār al-Fikr, 1967.

Amin, M. Masyhur, NU dan ljtihad Politik Kenegaraannya, Yogyakarta: al-Amin Press, 1999.

Arabi, Ibnu, "Konstruksi Islam Rahmah li al-'Alamin K.H. Ahmad Hasyim Muzadi”, Humanistika: Jurnal Keislaman, Vol. 4, No. 1, 2018.

https://www.ejournal.inzah.ac.id/index.php/ humanistika/article/view/162/128, diakses 21 April 2018.

Asjmuni, Rahman Abdul, Kaidah-kaidah Fikih (Qawa'id al-Fiqhiyyah), Jakarta: Bulan Bintang, 1976.

Asshiddiqie, Jimly, Gagasan Kedaulatan Rakyat dalam Konstitusi dan Pelaksanaannya di Indonesia. Jakarta: Ichtiar Baru-van Hoeve, 1994.

Geertz, Clifford, The Interpretation of Cultures, USA: Basic Books, 1973.

Dahlan, Moh., "Moderasi Hukum Islam dalam Pemikiran Ahmad Hasyim Muzadi", AlIhkam: Jurnal Hukum dan Pranata Sosial, Vol 11, No. 2, 2016.

http://ejournal.stainpamekasan.ac.id/index.php/ alihkam/article/view/1039/809, diakses 20 April 2018.

Fealy, Greg dan Barton, Greg (Ed.), Tradisionalisme Radikal: Persinggungan Nahdatul UlamaNegara. Yogyakarta: LKiS, 1997. 
Fitriah, Ainul, "Pemikiran Abdurrahman Wahid tentang Pribumisasi Islam", Teosofi: Jurnal Tasawuf dan Pemikiran Islam. Volume 3, Nomor 1 Juni 2013, http://teosofi.uinsby.ac.id/ index.php/teosofi/article/view/43/40, diakses 17 April 2018.

Gibb, H.A.R, The Modern Trends of Islam, Diterjemahkan oleh Machnun Husein, Cet. ke-2. Jakarta: Rajawali Pers, 1991.

Hadi, M. Khoirul, "Abdurrahman Wahid dan Pribumisasi Pendidikan Islam", Hunafa: Jurnal Studia Islamika, Vol.12, No. 1, Juni 2015.

Hamidah, "Pemikiran Neo-Modernisme Nurcholish Madjid-K.H. Abdurrahman Wahid: Memahami Perkembangan Pemikiran Intelektual Islam", Miqot: Jurnal Ilmu-ilmu Keislaman, Vol.35, No.1, 2011.

http://jurnalmiqotojs.uinsu.ac.id/index.php/ jurnalmiqot/article/view/132/122, diakses 17 April 2018.

I. Nurol, Aen I, Pemikiran tentang Nilai Kebenaran Ijtihad dan Perspektif Aplikasinya dalam Kehidupan Abad 21, Pidato Pengukuhan Jabatan Guru Besar dalam Ilmu Ushul Fiqh Fakultas Syari'ah IAIN Sunan Gunung Djati Bandung Sabtu, 21 September 2002 di IAIN Sunan Gunung Djati Bandung, 2002.

Iskandar, A. Muhaimin, Gus Dur, Islam dan Kebangkitan Indonesia. Yogyakarta: KLIK.R dan DPP PKB, 2007.

Jannah, Wirdatul, "Pemikiran Abdurrahman Wahid tentang Demokrasi Pluralistik dan Pengaruhnya di Indonesia", Jurnal Online Mahasiswa Fakultas IImu Sosial dan Politik Universitas Riau, Vol. 5: Edisi I Januari-Juni 2018, https://jom.unri.ac.id/ index.php/JOMFSIP/article/view/19235/18592, diakses 20 April 2018

Karim, Zaidan Abdul, Nidhamur al-Qadla fi alSyari'ati al-Islamiyah,Bagdad: Matba'atu al'Aini, 1983.

Kusumohamidjojo, Budiono,Filsafat Hukum: Problemtika Ketertiban yang Adil. Jakarta: Grasindo, 2004.

$\mathrm{L}$, Berger et al. Peter, The Desecularization of the World: Resurgent Religion and World Politics, Washington DC: Ethics and Public Policy Center, 1999.

Likadja, Jeffry Alexander Ch, “Memaknai 'Hukum Negara (Law Through State)' dalam Bingkai
'Negara Hukum (Rechstaat)', Jurnal Hasanuddin Law Review, Vol. 1, No. 1, April 2015. http:// pasca.unhas.ac.id/ojs/index.php/halrev/article/ view/41/40, diakses 20 April 2018.

Lukito, Ratno, Hukum Sakral dan Hukum Sekuler: Studi tentang Konflik dan Resolusi dalam Sistem Hukum Indonesia. Jakarta: Alvabet, 2012.

M. Tahir, Azhary M,Negara Hukum. Jakarta: Bulan Bintang, 1992.

Martahan, Sitompul Einar, NU dan Pancasila. Jakarta: Sinar Harapan, 1989.

Masykur, Musa Ali, Pemikiran dan Sikap Politik Gus Dur, Jakarta: Erlangga, 2010.

Mochtar, M. Akil, 2011. "Visi Pembangunan Sistem Hukum Indonesia", dalam http:// www.akilmochtar.com/wp-content/uploads/ 2011/06/, diakses tanggal 4 Februari2013.

Muzadi, Hasyim, Nahdatul Ulama di Tengah Agenda Persoalan Bangsa, Jakarta: Logos Wacana Ilmu, 1999.

Nawawi, Arief Barda, Beberapa Aspek Pengembangan Ilmu Hukum Pidana Menyongsong Generasi Baru Hukum Pidana Indonesia, Semarang: Pustaka Magister, 2011.

Nazir, Moh, Metode Penelitian. Jakarta: Ghalia, 1998. Noer, Deliar, Gerakan Modern Islamdi Indonesia 19001942. Jakarta: Lembaga Penelitian Pendidikan dan Penerangan Ekonomi dan Sosial, 1988.

Praja, Juhaya S, Filsafat Hukum Islam, Tasikmalaya: Lathifah Press dan Fakultas Syariah IAILM, 2009.

Praja, Juhaya S., Teori Hukum dan Aplikasinya, Bandung: Pustaka Setia, 2011

Program Pascasarjana, Panduan Akademik: Penulisan Tesis \& Disertasi. Bandung: UIN Sunan Gunung Djati Bandung, 2015.

Qomar, Mujamil, NU “Liberal” dari Tradisionalisme Ahlus Sunnah Wal Jamaah ke Universalisme Islam, Bandung: Mizan, 2002.

Rahardjo, Satjipto, Hukum dan Masyarakat. Bandung: Angkasa, 1980.

Rahman, Asjmuni, Kaidah-kaidah Fikih, (Qawa'id al-Fiqhiyyah), Jakarta: Bulan Bintang, 1976.

Rasyid, Muhammad Makmun, "Islam Rahmatan Lil Alamin Perspektif K.H. Hasyim Muzadi”, Episteme: Jurnal Pengembangan IImu Keislaman, Vol 11, No 1, 2016. http://ejournal. iain-tulungagung.ac.id/index.php/epis/article/ view/189/134, diakses 21 April 2018. 
Salles, Kamarudin dan Khoiruddin Bin Muhammad, "Gus Dur dan Pemikiran Liberalisasi", ArRaniry: International Journal of Islamic Studies, Vol. 1, No. 2, Desember 2014. http:// journalarraniry.com/ojs/index.php/jar/article/ view/17/17, diakses 17 April 2018.

Santalia, Indo, "K.H. Abdurrahman Wahid: Agama dan Negara, Pluralisme, Demokratisasi, dan Pribumisasi", Jurnal Al-Adyan, Vol.1, No. 2, Desember 2015.

Sjadzali, Munawir,Islam dan Tata Negara. Jakarta: UI Press, 1991.

Tolerations, dalam https://mail2.mpil.de/exchange/ mboecken /Entw\%C3\%BCrfe/Project Manager - Constitution Process - Governance.EML/, 2007.

Sularno, "Syariat Islam dan Upaya pembentukan Hukum Positif dilndonesia", diakses pada 05 Oktober 2012, dari http://journal.uii.ac.id/ index. php/JHI/article/viewFile/ 245/240.

Tahir, Azhary Muhammad, Suatu Studi Tentang Prinsip-prinsipnya Dilihat dari Segi Hukum Islam dan Implementasinya Pada Periode Negara Hukum Madinah dan Masa Kini, Jakarta: Bulan Bintang, 1991.
Thalib, Sajuti, Receptio A Contratrio, Hubungan Hukum Adat dan Hukum Islam. Jakarta: Bina Aksara, 1985

Usman, Mukhlish, Kaidah-kaidah Ushuliyah dan Fiqhiyyah,Jakarta: Gema Insani Press, 2000. Wahid, Abdurrahman, "Universalisme Islam dan Kosmopolitanisme Peradaban Islam", dalam Budhy Munawar-Rachman (ed.), Kontekstualisasi Doktrin Islam dalam Sejarah. Jakarta: Paramadina, 1995. , Islamku Islam Anda Islam Kita. Jakarta: The Wahid Institute, 2006.

, "Merumuskan Hubungan Ideologi Nasional dan Agama", dalam Kacung Marijan dan Ma'mun Murod al-Brebesy (Ed.), Abdurrahman Wahid Mengurai Agama dan Negara. Jakarta: Grasindo, 1999.

, "Sekali Lagi Tentang Forum Demokrasi", dalam Editor, Nomor 36/ tahun IV/25 Mei 1991, 1991.

Wasino, "Indonesia: From Pluralism to Multiculturalism", Paramita: Historical Studies Journal, Vol 23, No 2, 2013.

https://journal.unnes.ac.id/nju/index.php/paramita/ article/view/2665/2733, diakses 20 April 2018. 